WIDER Working Paper 2019/37

The contribution of services to trade and development in Southern Africa

Justin Visagie and Ivan Turok*

April 2019

United Nations University World Institute for Development Economics Research 
Abstract: Services are the fastest growing portion of world trade and now account for nearly a quarter of global exports. This presents opportunities for emerging economies to adapt and enter new markets. Many countries in southern Africa have struggled to diversify from a heavy reliance on primary commodities towards manufacturing industries. Tradable services could contribute to economic growth and development by bolstering industrial capabilities, facilitating productivity growth, and contributing directly to exports. The authors examine evidence on international services trade for the Southern African Development Community between 1995 and 2012, and supplement this with a review of Foreign Direct Investment from South Africa. Tradable services appear to have made a limited contribution to total trade for most countries, and there is little evidence of significant regional integration or specialization in higher value-added activities. The role of tradable services is an important policy and research agenda that warrants much more attention all round.

Keywords: tradable services, international trade, economic development, southern Africa JEL classification: F13, L80, O14, O55

* Human Sciences Research Council, South Africa; corresponding author: jpvisagie@hsrc.ac.za

This study has been prepared within the UNU-WIDER project on 'Southern Africa-Towards Inclusive Economic Development (SA-TIED)'.

Copyright (C) UNU-WIDER 2019

Information and requests: publications@wider.unu.edu

ISSN 1798-7237 ISBN 978-92-9256-671-5 https://doi.org/10.35188/UNU-WIDER/2019/671-5

Typescript prepared by Joseph Laredo.

The United Nations University World Institute for Development Economics Research provides economic analysis and policy advice with the aim of promoting sustainable and equitable development. The Institute began operations in 1985 in Helsinki, Finland, as the first research and training centre of the United Nations University. Today it is a unique blend of think tank, research institute, and UN agency — providing a range of services from policy advice to governments as well as freely available original research.

The Institute is funded through income from an endowment fund with additional contributions to its work programme from Finland, Sweden, and the United Kingdom as well as earmarked contributions for specific projects from a variety of donors.

Katajanokanlaituri 6 B, 00160 Helsinki, Finland

The views expressed in this paper are those of the author(s), and do not necessarily reflect the views of the Institute or the United Nations University, nor the programme/project donors. 
There appears to be a growing role for services in capturing and controlling value within global value chains (Kaplinsky 2005; OECD 2017). Technological change has enhanced the tradability of services insofar as delivery can be facilitated electronically, independently of physical proximity. Service exports have risen exponentially over the past few decades, from 9 per cent of global exports in 1970 to approximately 20 per cent in 2014 (Lougani et al. 2017; Stephenson and DrakeBrockman 2014). Lead multinationals are increasingly outsourcing lower-value activities, including labour-intensive manufacturing, and maintaining control of high-value services such as marketing, design, R\&D, and aftermarket sales (Fessehaie 2017; Kaplinsky and Morris 2016).

The importance of tradable services extends beyond their direct contribution to total exports. High-level tradable services bolster other industries by improving their competitiveness and by enabling products to be adapted to new markets. Strengthening high-order service functions could enhance the positioning of firms within global production networks and act as a stimulus to industrial development (Fessehaie 2017; Heuser and Mattoo 2017). The role of services is bound to become even more important with the proliferation of disruptive technologies related to robotics, artificial intelligence, and the 'internet of things', which are set to change the nature of work in dramatic ways (McKinsey Global Institute 2017; World Bank 2019).

It is important for countries in Southern Africa to adapt and make the most of changes to the global landscape of production and trade. In South Asia, for instance, countries such as India, Pakistan, and Sri Lanka have shown notable success in breaking into IT- and health tourism-related markets (Eichengreen and Gupta 2011; Ghani 2009; Noland et al. 2012), and there are signs that emerging economies, most notably China, are beginning to consolidate a greater share of production locally through vertical integration of intermediary inputs and a greater role for highorder and skills-intensive goods and services (McKinsey Global Institute 2019).

Modern services depend upon the availability of specialized skills and an enabling regulatory regime, which are lacking in many countries in Southern Africa. Regional integration could be an important tool for broadening markets, deepening capabilities, and improving access to a range of higher-order services in Southern Africa. The Southern African Development Community (SADC) Regional Industrialisation Strategy and Roadmap 2015-2063 acknowledges a strategic role for tourism-, financial services-, and ICT-related value chains in the region (SADC 2015). South Africa, in particular, has relatively advanced capabilities in the finance, telecommunications, and construction/engineering sectors, which could benefit the region. The development of regional clusters of firms in related services could help raise productivity by increasing the effective market size, improving the availability of skills, developing suppliers, encouraging technology spill-overs, and sharing the costs of specialized infrastructure (Glaeser 2011; Storper et al. 2015).

This paper explores the available evidence on the rise of services trade and its contribution to development in the SADC region over the past two decades. Could service-based exports offer opportunities for countries in Southern Africa to accelerate economic growth? What is the absolute and relative size of service exports in comparison with merchandise trade? Which service sectors contribute to growth and what is the skill-intensity of the export basket? Is there any sign of the emergence of regional value chains in modern services to support industrialization within the $\mathrm{SADC}$ region?

The focus of the analysis is on evaluating flows of international balance of payments data, making use of a new dataset released by Organisation for Economic Co-operation and Development 
(OECD) and World Trade Organization (WTO). The Balanced Trade in Services (BaTIS) dataset provides a comprehensive picture of international services trade, including trade bi-laterals between source and partner countries, broken down into detailed services sub-sectors. This is supplemented by information on foreign direct investment (FDI) from South Africa into the region, as well as a review of recent headlines in the South African mainstream media and more than a dozen interviews with CEOs of South African service multinationals and relevant officials.

The overall picture is that services-based trade did not feature prominently in the SADC region and showed limited growth over the period 1995-2012. The composition of service exports in Southern Africa was heavily skewed towards traditional sectors, although there were signs of shifts in consumption towards modern services (from a low base). High-level services were mainly imported from foreign markets, which suggests missed opportunities for African suppliers of knowledge-intensive services. Intra-African trade flows were consistently a small minority of all services trade in the region, the majority of trade flowing between Southern Africa and Europe. South Africa was by far the largest player among the SADC countries and could perform better in exporting its know-how in sectors such as IT, engineering, and construction to the rest of Africa if it were properly supported.

\section{The role of services trade in economic development}

Services make up the largest share of total production in advanced economies. The OECD (2018) estimates that services account for half of all value addition amongst tradable sectors in the United States and have become the fastest growing productive sector in Europe. The international evidence suggests that, as countries become richer, older, and more urbanized, they consume relatively more services (OECD 2017).

More contentious is the potential for services to promote structural transformation in less developed countries (Di Meglio et al. 2018; Ghani and O'Connell 2014; Gollin et al. 2016; Rodrik 2018). The arguments against services-led development relate to: a lack of precedent considering the historical role played by manufacturing in the transition of today's high-income countries; the inherent dependence on domestic markets by less tradable service industries; and the skill-intensity of high-order services.

History makes a strong case for the role of manufacturing in facilitating the rise of prosperous economies, and the recent dramatic progress made by China and other East Asian countries supports this view. Manufacturers can benefit from powerful scale economies, which raise productivity and push up wages as volumes rise in servicing global demand. Contemporary industrial policy in Africa widely acknowledges the strategic role of manufacturing-led export growth in structural transformation. Despite an emphasis in policy on fast-tracking manufacturing, the manufacturing sector in most African countries has stagnated or even declined over the past few decades (Razzaque 2017; Rodrik 2018). Some commentators have pointed out that there may be insufficient room for extensive industrialization in Africa due to strong competition from lowcost producers in East Asia and shifts in global consumption away from lower-value manufactured goods (Nayyar et al. 2018; Rodrik 2016). Service-based growth may be attractive because it offers an alternative or complementary path to development in addition to growth in low-value manufacturing.

Another common apprehension with services-based economies is that they appear to demand a relatively skilled workforce (Bhorat et al. 2018; Rodrik 2018). The concern is that services-led transformation will leave large numbers of unskilled workers behind. For example, it is argued that 
it is far easier to transform a farm worker into a shop floor worker than into a computer programmer. This line of reasoning is fairly superficial considering that not all tradable service jobs are high-tech, with many lower-end jobs available in tourism, travel, retail, and logistics. Labourintensive services may employ more than seven times as many people as labour-intensive manufacturing (McKinsey Global Institute 2019). At the same time, modern manufacturing has become increasingly capital- and skills-intensive, whilst advances in artificial intelligence and automation threaten the future of many lower-end manufacturing jobs (Hallward-Driemeier and Nayyar 2017; World Bank 2019; World Economic Forum 2016). The great heterogeneity in the service sectors in terms of value-addition, skills profile, and knowledge-intensity also needs to be considered.

Services are commonly depicted as less tradable than manufactured goods. For example, it is argued that the demand for and price of haircuts depends entirely on the health of the local economy, whilst a producer of hair products can access global demand. An alternative perspective is that services have always been highly tradable simply by being embedded into the production processes of traded goods. Services are critical inputs across the entire lifecycle of most goods, from $\mathrm{R} \& \mathrm{D}$ during product origination, to technical testing and process refinement during manufacturing, marketing and logistics services during distribution, and aftermarket support during sales and client retention. Global value chains have become increasingly fragmented, enabling a growing range of service inputs and creating a trend towards higher levels of 'servicification' in manufacturing (Cooke 2017; Fessehaie 2017). A report by the McKinsey Global Institute (2019) suggests that investments in intangible assets (which are services-driven) such as $\mathrm{R} \& \mathrm{D}$, marketing, and intellectual property have more than doubled in global value chains from 5.5 per cent as a share of revenue in 2000 to 13.1 per cent in 2016.

A related weakness of services-based trade is that the means of exchange is more complex than the traditional transportation of physical goods over borders. For instance, some services must be exported through the physical movement of persons (either consumption of tourists abroad, or travel of a producer into a foreign market) or by permanently setting up a base in a foreign market. ${ }^{1}$ Service exporters may need to navigate a number of institutional and regulatory barriers in effectively operating across different countries. Nevertheless, advances in technology and modern air travel have enabled service exports to flourish over the past few decades. Services can in some cases be stored digitally and transmitted electronically at virtually no cost. In fact, the WTO has recently recorded that the relative growth of services outstripped that of merchandise trade (WTO 2016, 2017). This is not just a trend in modern industrialized economies. The WTO (2016) reports that the service exports of the Least Developed Countries grew twice as fast as those of the rest of the world between 2005 and 2015 .

To argue that industrial policy must choose between promoting services and promoting manufacturing is arguably misdirected in the light of their co-dependence. The emphasis should be on raising productivity, increasing competitiveness, and opening up new markets in sectors where African countries have a comparative advantage. Services have an important role to play in Africa's structural transformation, either directly as a tradable export, or indirectly, as an input in production or as an enabler of participation in global value chains. African economies tend to be dominated by minerals extraction and basic commodity exports, which occupy subordinate positions within global production networks. Higher-level services could empower firms to move

\footnotetext{
${ }^{1}$ The WTO measures the international trade of services under the General Agreement on Trade in Services (GATS) across four modes of supply: Mode 1: Cross-border supply; Mode 2: Consumption abroad; Mode 3: Commercial presence; Mode 4: Presence of a natural person. Some of the technicalities related to measuring services trade are discussed further in Section 3 on data and methods.
} 
up value chains and unlock beneficiation. Examples include $R \& D$ services in upgrading agricultural production methods, finance and marketing services in moving farmers into agroprocessing, or engineering services in developing new mining equipment and minerals-processing operations for the mining sector.

Obvious priorities for any policy supporting tradable services are creating openness to trade and, particularly, enhancing regional integration across Africa. Countries in sub-Saharan Africa (SSA) would be better off increasing exports (and imports) in the region and avoiding zero-sum protectionism. This is particularly important for a number of landlocked countries and economies with very small domestic markets in Southern Africa. Two-thirds of world trade is in intermediate goods and services, rather than final products, which highlights the scale and complexity of modern production networks (Baldwin and Lopez-Gonzalez 2015). The emphasis should be on building up clusters of firms that co-locate to competitively service a regional market. The development of area-based competencies would allow firms to share in the benefits of specialized infrastructure, a deeper pool of proficient labour, the specialization of suppliers, the diffusion of new technologies, and tacit knowledge amongst the network (Glaeser 2011; Storper et al. 2015).

The African market is anticipated to expand exponentially over the next few decades, fuelled by urbanization and population growth. This could be a massive boon for economic development on the continent provided that population growth can be translated into local jobs and incomes. The current service import basket for African countries is dominated by foreign suppliers of highervalue services, including IT, finance, and business services. This makes a good case for replacing foreign firms with African suppliers if local markets can be effectively integrated and domestic capabilities developed.

However, trade between African countries remains fragmented-held back by a range of physical and institutional barriers such as poor road and rail infrastructure, badly managed customs and border controls, and general political and economic instability. For instance, the United Nations Economic Commission for Africa (2018) found that African firms faced higher tariffs when exporting within Africa than outside it. Intra-African trade is estimated to account for only 15 per cent of total trade from Africa (African Development Bank et al. 2017). Non-tariff barriers to services trade can also impose sizable, albeit more hidden, costs. The OECD (2017) has suggested that tariff-equivalent costs from behind-borders restrictions on services typically exceed those of direct costs from tariffs. The former come in a variety of forms, such as limitations to foreign equity, differences in standards and rules for licensing, thresholds for local content in state-related contracts, and restrictions on the movement of persons. Trade negotiators need to work closely with the private sector in order to identify where the biggest barriers to trade lie.

A review of a number of trade agreements over the past two decades suggests that opportunities for services-based trade have steadily expanded. This expansion began with the WTO's adoption in 1995 of the General Agreement on Trade in Services (GATS), which extended global trade negotiations to explicitly include international services trade. Southern African countries all committed to 'substantially' removing services trade barriers, particularly those related to tourism and travel (Cattaneo 2017). Nevertheless, on deeper analysis of different modes of supply, Kruger (2011) found that none of the countries in SSA actually lowered their services trade barriers. The average level of responsiveness was in effect only 13 per cent when taking into account the total number of commitments that could have been made across all sectors and modes of supply. South Africa was the most progressive in agreeing to 46 per cent of the total possible commitments and Madagascar the least progressive at 1.25 per cent.

Regional trade agreements have similarly begun to focus on the liberalization of services-based trade. For example, in the early 2000s the SADC began negotiations for a framework to open up 
services markets, which was finally adopted as the SADC Trade in Services Protocol in 2012 (Cattaneo 2017). This committed SADC countries to the liberalization of services every three years and focused on six priority sectors: communication services, construction services, energy-related services, financial services, tourism services, and transport services.

Other regional economic communities across Africa have also adopted specific service-based trade charters. For example, the Common Market for Eastern and Southern African States (COMESA), the EAC (East African Community), and their integration with the SADC through the Tripartite Free Trade Area (TFTA) included explicit commitments to regional services trade integration. There is similarly growing momentum behind the African Continental Free Trade Area (AfCFTA), which is set to include a protocol for services trade that would mean explicit commitments to services liberalization through lowered tariffs in targeted service sub-sectors as well as reductions in non-tariff barriers, such as mutual recognition of standards, simplification of licensing procedures, and streamlined certification. The AfCFTA could develop into the world's largest free trade area if all 55 member states of the African Union are incorporated; it would cover 1.2 billion people, with a combined GDP of US\$3.4 trillion (Parshotam 2018).

There appears to be a real opportunity for forward-looking service firms to ride the momentum behind Africa's regional trade agreements. However, trade agreements need to do more than merely reduce tariff barriers. African countries would benefit greatly from genuine trade integration that increases consumer demand and improves access to capital, technology, and scarce skills and expertise. African countries need to work hard to identify areas where they have relative strengths and can support each other through regional trade and cooperation.

Critical, too, is the role and power of South Africa as a relative hegemon in the SADC region. South Africa has a lot to offer the rest of Africa through high-order services such as finance and insurance, telecommunications and IT, and engineering and construction, but a recent report on South Africa by the World Bank (2018) identified low levels of competition and integration in global and regional value chains as one of the top five constraints to growth in the country.

\section{Data and methods}

The availability of international services trade statistics has come a long way since the signing of the GATS treaty by members of the WTO in 1995. The quality and sophistication of services trade data have progressed steadily following the release of guidelines and updates in the system of classifications by the WTO over the past two decades. Balance of payments data for services are now available for almost all countries, although these tend to be limited in detail for many developing countries. For instance, there remain significant gaps in reporting on the size and composition of South-to-South trade or in accounting for detailed categories of service-sector trade.

The challenge of assembling reliable services trade data is in part due to the greater complexity in which services are delivered between producer and consumer in comparison with merchandise trade. The GATS identifies four modes through which services can be traded between any two countries.

- Mode 1: 'cross-border': when the service is traded across borders in a similar manner to goods;

- Mode 2: 'consumption abroad': occurs during business and personal travel abroad;

- Mode 3: 'commercial presence': when a foreign affiliate is present in a destination market; 
- Mode 4: 'movement of natural persons': where an individual travels to a destination market to offer a service.

These four modes of supply have two important implications for interpreting balance of payments data.

First, all records of Mode 2 supplies (services delivered through consumption of goods and services abroad) are assigned to the service sector of 'travel'. Whilst travel tends to mean 'tourism', there could be other reasons for travelling abroad, such as to gain access to business, education, or health-related services. Hence, there is more than likely some spill-over between traditional 'travel' and more modern service consumption that we are unable to control for when reporting on the composition of services trade.

Second, data on Mode 3 supplies (services delivered through a commercial presence in a foreign market) are not included in balance of payments records. This is because companies with a base in a foreign market are considered 'resident' after operating in that country for more than a year and hence fall away from subsequent balance of payments records. This rule similarly applies to migrant workers who are abroad for more than 12 months (which can lead to an underestimation of Mode 4 supplies). The amount of total services trade derived from foreign operations may account for as much as two-thirds of total services trade, according to estimates by the WTO (Hoekman and te Velde 2017; Rueda-Cantuche et al. 2016). The WTO Manual on Statistics of International Trade in Services recommends that countries compile 'foreign affiliates statistics' (FATS) to account for such supplies. Unfortunately, FATS are available for only a small minority of highincome countries.

We make use of a relatively new dataset, released by the OECD and WTO in 2017, which attempts to provide 'complete, consistent and balanced bilateral trade in services statistics' (Fortanier et al. 2017). Balanced Trade in Services Statistics (BaTIS) data fill in all of the balance of payments data gaps by using mirror data (cross-checking of recorded exports and imports between countries) or statistical modelling to forecast values for missing records. ${ }^{2}$ The end result is a complete set of balance of payments services trade bi-laterals for 191 economies, broken down into 11 main service categories for the years 1995-2012.

Closer inspection of the BaTIS data for African countries suggests the need for care when interpreting some of the results, however. In particular, African countries do not record details about the country of origin (for imports) or the country of destination (for exports) in balance of payments service statistics (only the total value of services trade with rest of the world is recorded). The assembly of mirror data (cross-checking records of imports and exports recorded between countries) can overcome some of this inherent weakness, but the BaTIS estimates of trade flows between any two particular African countries admittedly rely heavily on forecasting to fill this gap. There is also a fair degree of forecasting in estimates which are disaggregated into more detailed service sub-sectors. For example, the records of South Africa's services trade with countries in Europe are more dependable than those of other African countries, where missing information has been estimated. We are careful to highlight where there is potential for error when discussing the results.

\footnotetext{
${ }^{2}$ See Fortanier et al. (2017) for a detailed account of the BaTIS methodology. The approach leverages all available official data, and combines these with derivations, backcasting techniques, interpolation, predictions derived from regression models, and cross-checking of mirror data in records of exports and imports between countries.
} 
This is followed by an examination of FDI statistics for South Africa as a useful indicator of the size and composition of foreign operations (i.e. Mode 3 supplies) by South Africa-based firms into the rest of Africa. The data are sourced from the fDi Markets database ${ }^{3}$, which is based on systematic monitoring of the local and global media. We supplement these data with our own knowledge of local headlines and interviews with CEOs of South African service multinationals and relevant government officials. We do not pretend that this offers a complete account of investments into Africa, but it should at least provide some indication of the direction of investments in larger projects. We focus on South Africa as the largest economy in Southern Africa and therefore a popular base for establishing African headquarters amongst global conglomerates.

\section{The relative size and composition of international services trade in SADC countries}

Figure 1 presents an overview of the trajectory of total service exports for the seven largest economies in the SADC region over the period 1995-2012. These trends were broadly representative of other countries in the region. The figure shows that service-based exports were fairly stagnant in the 1990s and even declined in Zambia, the DRC, and Botswana until reaching a turning point in 2002. The global commodity boom of the mid-2000s, coupled with favourable interest rates, was accompanied by a rapid expansion of service exports for all SADC countries, which peaked in 2008, before the onset of the global financial crisis. Average export growth for SADC countries between 2002 and 2008 was above 10 per cent per annum, although a large part of this solid performance was probably due to the impact of favourable foreign exchange. ${ }^{4}$ In the wake of the financial crisis, service exports dipped considerably for the majority of countries but then appeared to catch back up, averaging over 4 per cent growth year on year between 2009 and 2012.

Stronger performance of tradable services since the turn of century for Southern African economies may warrant some enthusiasm for the potential role that services trade could play in the region. Crucial is the nature of the relationship between international services trade and domestic growth. In other words, did expanding services exports lead or lag local economic growth? The complexity of the real world makes it difficult to offer any conclusive answers but a reflection on the size and growth of services trade relative to other economic indicators goes some way to contextualize trade in services trends.

\footnotetext{
${ }^{3}$ See www.fdimarkets.com

${ }^{4}$ Volatility in exchange rates can significantly impact on the balance of payments, independently of any real change in total production, particularly for less developed and oil-exporting countries.
} 


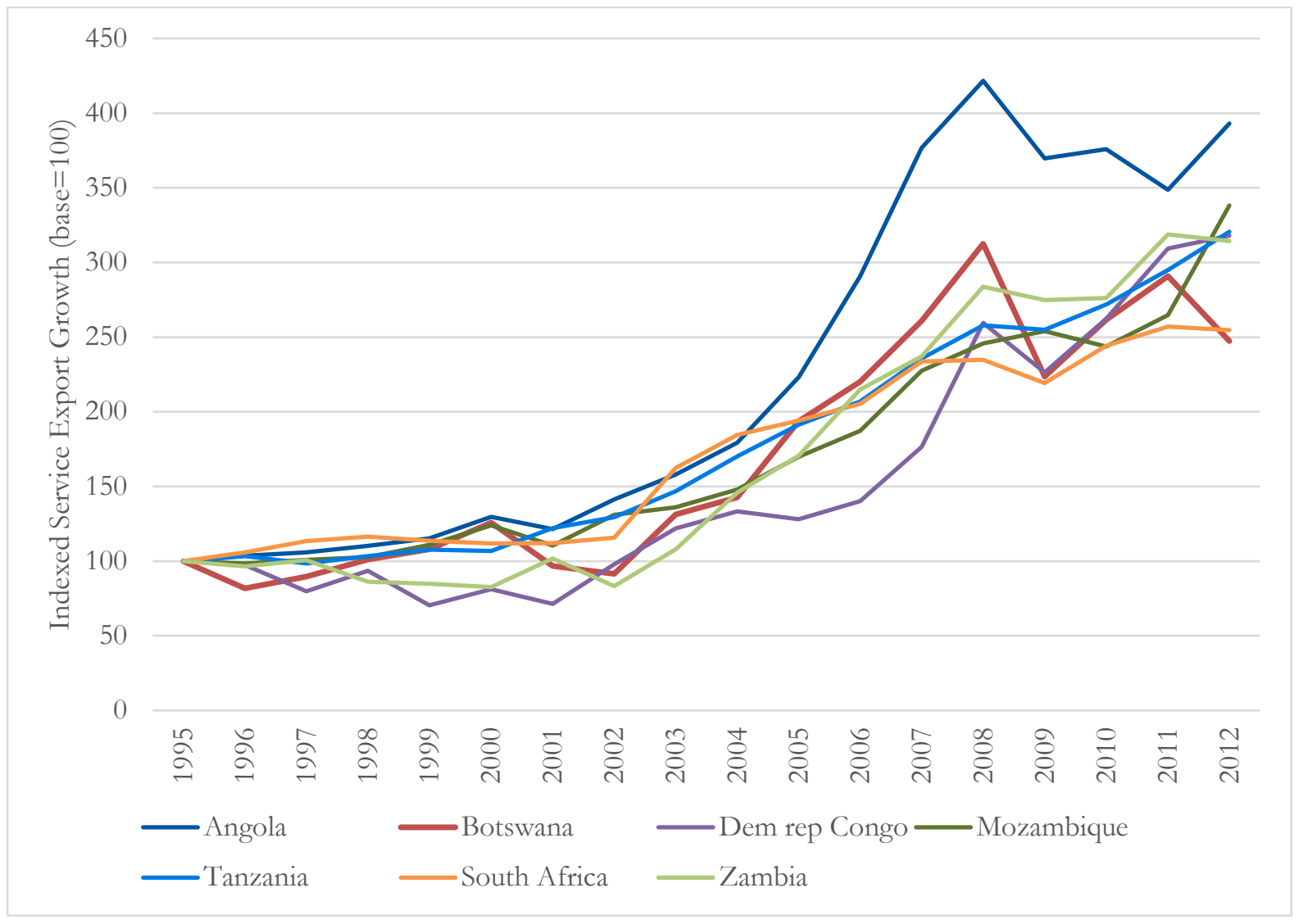

Note: Trade flows are converted to constant prices using a US GDP deflator.

Source: OECD-WTO BaTIS database (2018).

Table 1 shows the relative size of services exports to total exports (merchandise + services exports) and to GDP across SADC countries in 2012. In most SADC countries services made up less than 15 per cent of total export trade, with some notable exceptions: Mauritius, Seychelles, Madagascar, and Tanzania all relied more heavily on tourism. A similar pattern is evident if the size of services exports is compared with GDP, although the shares are understandably lower. These comparisons say nothing about the contribution of services to domestic value added but do imply that the export of services was of limited importance to many SADC countries, particularly when compared with traditional merchandise trade.

The second half of the table reports on the correlation between services export growth and GDP growth over the period 1995-2012 and further breaks down services export growth into its subsectors. The results are fairly mixed, with roughly half of SADC countries managing to expand services exports ahead of economic growth. The large increases in services exports recorded for Angola and Mozambique actually lagged domestic performance and were probably following oil export windfalls rather than leading economic recovery in these countries. Standout performers were Seychelles, South Africa, and Madagascar, all of which grew their services exports at 1.5 times the rate of GDP growth. 
Table 1: Relative size and growth of services exports

\begin{tabular}{|c|c|c|c|c|c|c|c|c|c|c|c|c|c|c|c|c|}
\hline & ANG & BOT & DRC & COM & LES & MAD & MAU & MAL & $\mathrm{MOZ}$ & NAM & SEY & SWA & TAN & SA & ZAM & ZIM \\
\hline \multicolumn{17}{|c|}{ Relative size of services exports in 2012} \\
\hline$\%$ of total exports & $1.1 \%$ & $11.6 \%$ & $3.2 \%$ & $78.2 \%$ & $4.1 \%$ & $45.9 \%$ & $56.3 \%$ & $7.6 \%$ & $17.0 \%$ & $18.3 \%$ & $54.6 \%$ & $8.6 \%$ & $32.1 \%$ & $15.0 \%$ & $9.4 \%$ & $7.9 \%$ \\
\hline$\%$ of GDP & $4.3 \%$ & $2.1 \%$ & $3.3 \%$ & $13.8 \%$ & $4.8 \%$ & $11.5 \%$ & $29.2 \%$ & $3.0 \%$ & $5.5 \%$ & $8.5 \%$ & $82.5 \%$ & $3.3 \%$ & $6.9 \%$ & $4.1 \%$ & $3.9 \%$ & $3.9 \%$ \\
\hline \multicolumn{17}{|c|}{ Relative growth of services exports 1995-2012: (Ratio \% $\triangle \exp \% \triangle \mathrm{GDP}$ ) } \\
\hline Total services & 0.5 & 1.1 & 0.9 & 1.2 & 1.2 & 1.4 & 1.2 & 0.7 & 0.9 & 1.4 & 1.8 & 1.2 & 0.7 & 1.6 & 0.7 & 0.2 \\
\hline Transport & 0.3 & 1.3 & 1.0 & 0.8 & 0.9 & 1.2 & 1.0 & 0.4 & 0.7 & 1.7 & 1.2 & 0.9 & 0.6 & 1.0 & 0.7 & 0.5 \\
\hline Travel & 0.4 & 1.1 & 1.0 & 1.4 & 1.2 & 1.4 & 1.0 & 0.7 & 1.0 & 0.9 & 2.1 & 0.7 & 0.7 & 1.7 & 0.8 & 0.4 \\
\hline Comms. & 0.3 & 1.9 & 0.8 & 5.1 & 2.6 & 1.7 & 6.2 & 0.9 & 1.2 & 1.4 & 3.7 & 1.2 & 0.7 & 1.5 & 0.6 & -0.4 \\
\hline IT & 0.8 & 4.6 & 1.5 & 9.3 & 0.0 & 2.6 & 4.6 & 2.3 & 2.2 & 3.8 & 6.2 & -0.5 & 1.5 & 3.1 & 1.2 & 3.8 \\
\hline Finance \& ins. & 0.3 & 1.1 & 1.5 & 1.7 & -0.2 & 1.7 & 5.9 & 1.5 & 0.5 & 2.2 & 2.3 & 0.3 & 0.5 & 1.7 & 0.9 & -4.9 \\
\hline Construction & 0.6 & 3.6 & 1.3 & 9.8 & -0.1 & 0.3 & 4.4 & 1.1 & 1.6 & 2.4 & 1.2 & 4.5 & 1.9 & 1.4 & 0.8 & 0.1 \\
\hline Bus. services & 0.7 & 0.9 & 0.5 & 2.0 & 3.3 & 1.7 & 2.3 & 1.1 & 1.2 & 3.2 & 2.2 & 2.3 & 1.2 & 2.2 & 0.6 & 1.1 \\
\hline
\end{tabular}

Source: OECD-WTO BaTIS database (2018). 
Examining the growth rate for specific services sub-sectors deepens our understanding of the nature of services growth over the period. Traditional sectors such as transport and travel tended to keep pace with or fall behind GDP growth, whereas modern services generally registered much higher rates of growth. For instance, the IT sector grew at nearly three times the rate of GDP across the sample of SADC countries and (tele)communications grew at twice the rate of GDP. The three leading export services sectors for SADC countries over the period were IT, communications, and construction, whilst transport and travel were the slowest growing sectors. This points to the growing importance of high-order services in the export basket emanating from Southern Africa.

However the case for modernization in the services export basket of African countries should not be overstated. Figure 2 sets out the relative contribution of each services sub-sector to total exports and clearly shows how modern services remained a small proportion of total exports in 2012. The combined total of IT and (tele)communications exports never made up more than 10 per cent of total exports in any country and was generally less than 5 per cent. The business services sector, which includes a range of modern professional services, accounted for 15 per cent of total exports on average, although this category also includes a number of undefined service activities. ${ }^{5}$ In comparison, the traditional sectors of travel and transport jointly comprised 70 per cent of the export basket on average for SADC countries in 2012. Essentially, the better performance of modern services in comparison with traditional services came off a much lower base and therefore had only a weak influence on the aggregate performance of total services growth. The bottom line was that traditional services needed to be at least growth-neutral if modern services were to tilt aggregate performance into the positive.

The distinctive trends in traditional and modern services carried through into differences in the composition of services exports and imports from the SADC region. Figure 3 provides a highlevel comparison of such differences split across three categories of services: 'traditional', 'modern', and 'government'. 'There was a large difference in the absolute size of SADC exports and imports, which resulted in a sizable balance of payments deficit in 2012 of US $\$ 18.5$ billionas much as half of total services exports in $2012 .{ }^{7}$ Closer examination suggests that the deficit was driven mainly by net deficits from imports of modern services. SADC countries were net importers in most services sectors, with the notable exception of travel, which totalled US $\$ 8$ billion net travel exports in 2012. The relative strength of travel exports highlights the importance of traditional tourism exports for bolstering African trade and improving access to foreign exchange.

\footnotetext{
5 'Business services include: (i) Research and development services, (ii) Professional and management consulting services and (iii) Technical, trade-related and other business services. (i) Research and development services consist of services that are associated with basic and applied research, and experimental development of new products and processes. (ii) Professional and management consulting services include (a) legal services, accounting, management consulting, managerial services, and public relations services; and (b) advertising, market research, and public opinion polling services. (iii) Technical, trade-related, and other business services include: (a) architectural, engineering, and other technical services; (b) waste treatment and depollution, agricultural, and mining services; (c) operating leasing services; (d) trade-related services; and (e) other business services n.i.e.' (WTO 2017: 89).

6 'Traditional' incorporates the travel and transport sectors; 'Modern' incorporates the telecommunication, IT, construction, finance and insurance, and business services sectors; and 'Government' includes government goods and services n.i.e. (not incorporated elsewhere), which include goods and services supplied to embassies or other enclaves and to diplomats and military personnel.

${ }^{7}$ A large part of the trade deficit is driven by excessive services imports from Angola (see Figure 4). If Angola is excluded from the analysis, the trade deficit is much lower but still significant at 20 per cent of total services exports.
} 
Figure 2: Composition of services exports, 2012

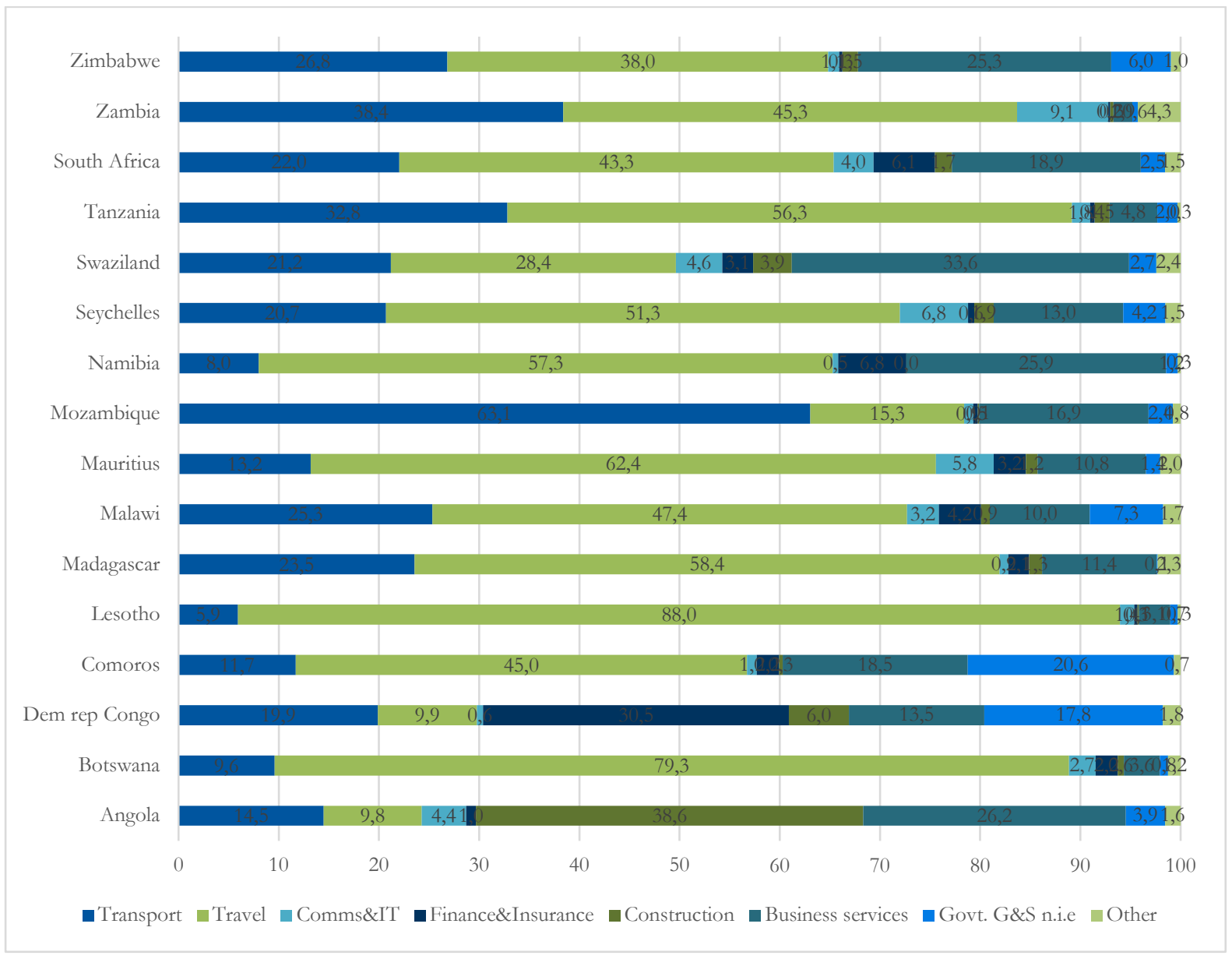

Source: OECD-WTO BaTIS database (2018).

Figure 3: Modern and traditional services imports and exports across SADC, 2012

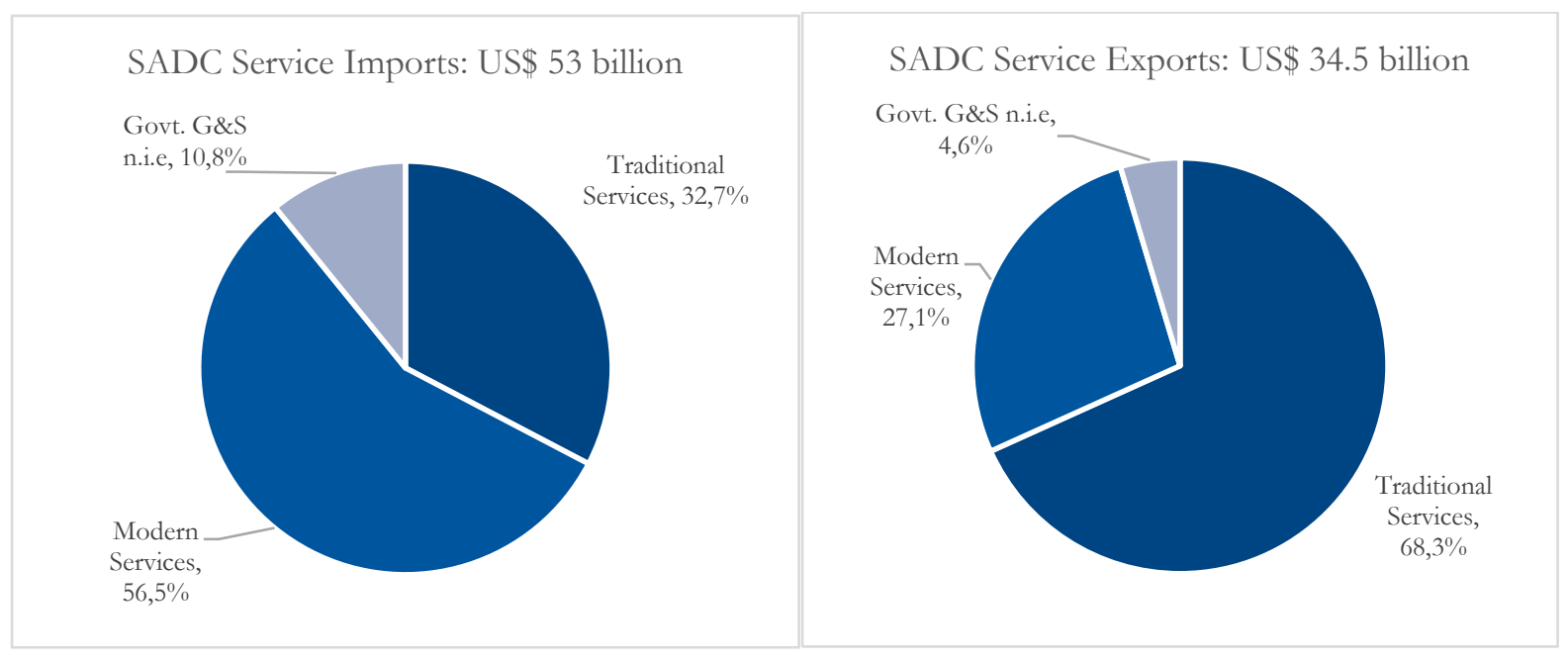

Notes: The percentages reflect the average for SADC countries.

Source: OECD-WTO BaTIS database (2018). 
In summary, Southern African economies did not show much sign of accelerating their international services trade through the contribution of large and propulsive service industries, as with ICT in the case of East Asia. Total services remained a fairly limited share of total goods and services trade, and modern services were too small to make much impact on services trade despite performing relatively better. High-order services capabilities would need to grow exponentially to occupy a more significant place in Africa's services export basket in the near future.

\section{Flows of international services trade for SADC countries between regions}

We end our analysis of the balance of payments data by exploring the nature of services trade specifically between SADC countries and by looking for evidence of the SADC as an effective regional trade bloc.

Figure 4 presents the relative contribution of each partner to total international services trade in the region. The figure shows that the absolute size of trade in the region was dependent on South Africa, which accounted for nearly half of total services exports in 2012 and was the second largest services exporter on the continent (after Egypt). Angola was ranked second for total services exports amongst SADC countries but incurred an immense trade deficit due to much higher services imports. Mauritius, on the other hand, accumulated a healthy services trade surplus and outperformed its economic rank as eighth largest economy in the SADC but third largest exporter of services. Outside the top three SADC exporters, the remaining 13 countries accounted for less than 30 per cent of exports (or imports) at generally less than 3 per cent each. This highlights the importance of regional trade in bolstering the position of many smaller and landlocked economies in Southern Africa, which made very limited contributions to total trade if viewed in isolation.

Figure 4: Total services trade to all regions, 2012

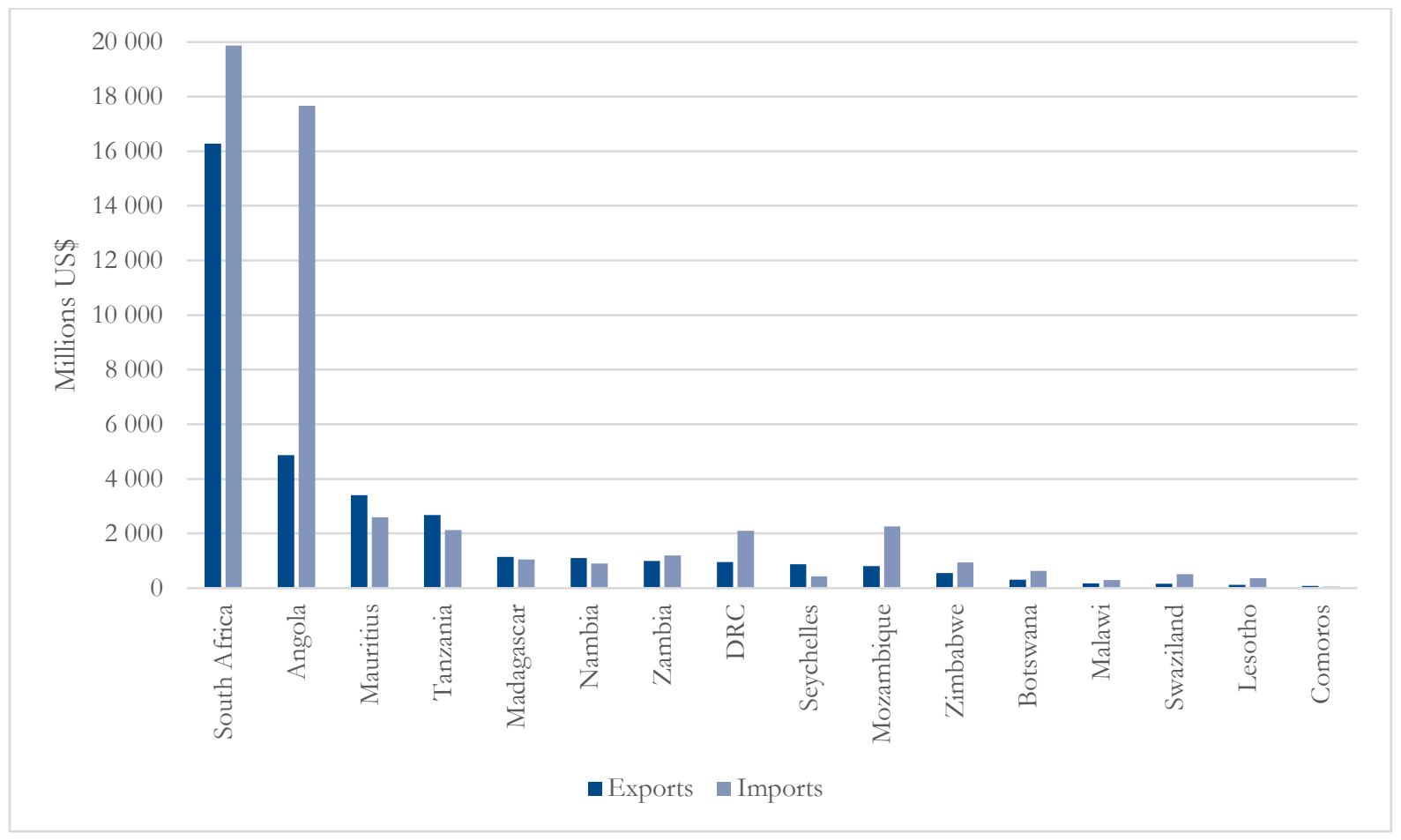

Source: OECD-WTO BaTIS database (2018). 
Figure 5: Total services exports by major regions, 2012

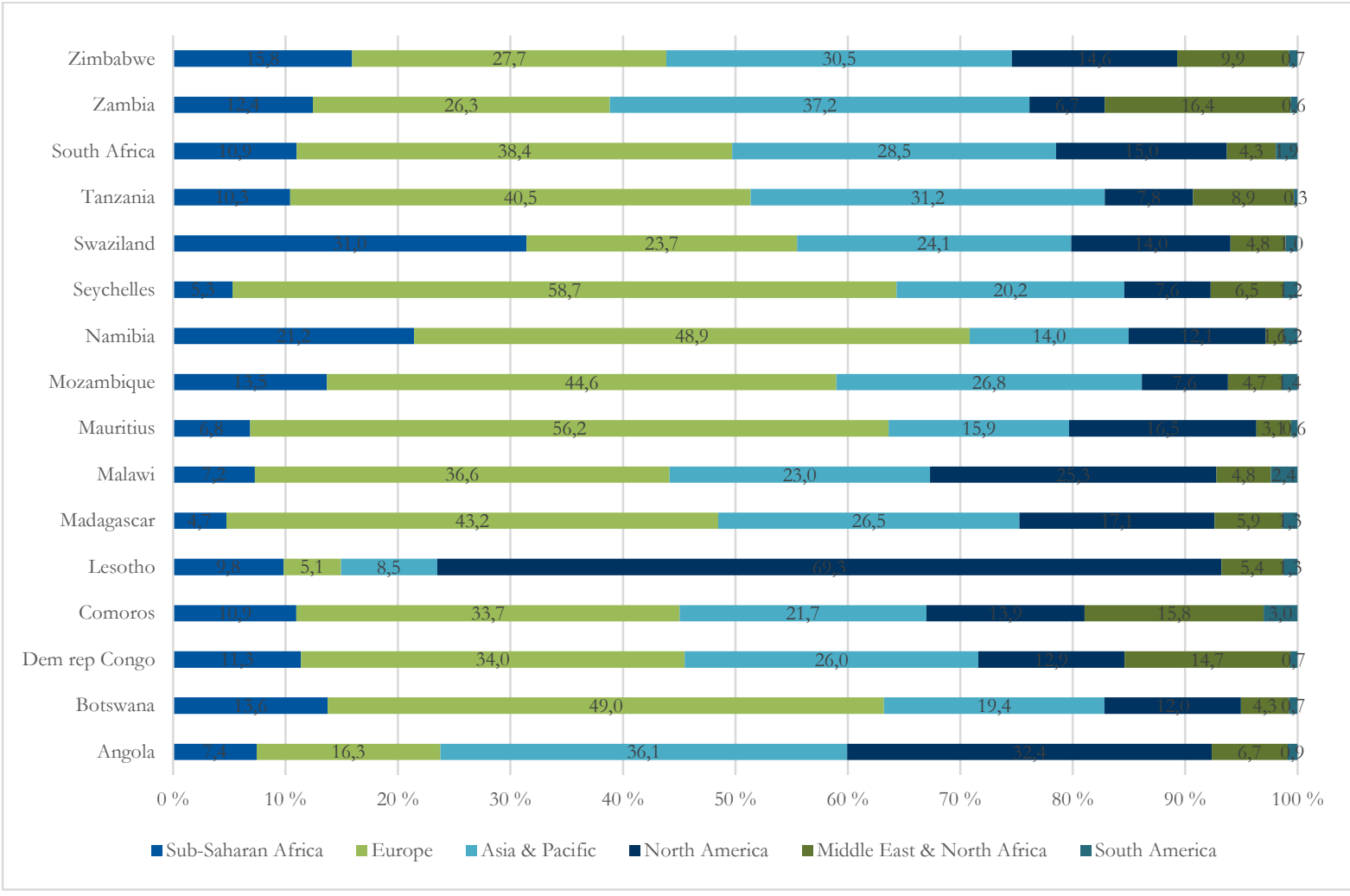

Source: OECD-WTO BaTIS database (2018).

Figure 6: Total services imports by major regions, 2012

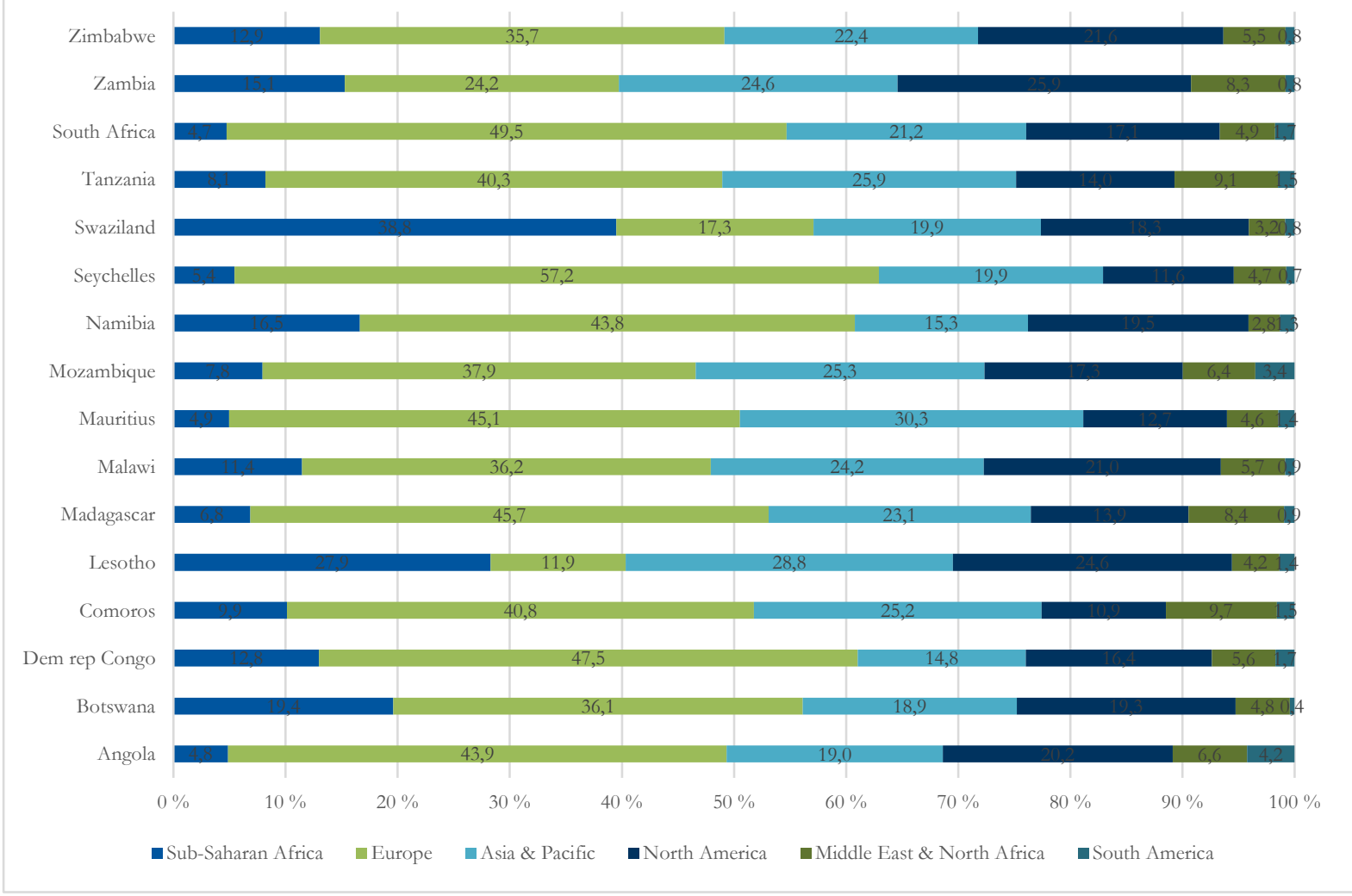

Source: OECD-WTO BaTIS database (2018). 
Figures 5 and 6 break down flows of services trade according to trading partners aggregated across the major world regions. SSA did not feature as a major trading partner for any of the countries in the SADC - with the possible exception of Swaziland and Lesotho, which have closer ties to South Africa. Exports into SSA typically comprised less than 15 per cent of total trade, the majority of exports flowing to Europe, Asia, or North America. A similar pattern is applicable to total services imports, the majority of foreign services coming from Europe, Asia, and North America. We estimate that approximately 55 per cent of services trade from SADC countries was with more advanced nations in Europe or North America, whether importing from or exporting to these regions. South Africa is the largest market in Southern Africa but imported only 5 per cent (and exported 11 per cent) of its traded services from/to its African neighbours.

There are admittedly troubles with this form of data-trade bi-laterals between less developed countries depend heavily on modelled estimates-but it is unlikely that data problems could explain away such clear patterns. The picture that emerges consistently depicts only a limited role for intra-African trade amongst SADC countries.

Figure 7 probes for differences in the sectoral composition of trade for the SADC's four largest services-exporting countries (which make up four-fifths of exports for the region) divided across major trading partners and split between traditional and modern services. ${ }^{8}$ There appears to be some significant lessons to be gleaned, limitations in the data at a fairly high level of disaggregation notwithstanding.

First, each of these countries was heavily dependent on the import of modern services from outside SSA. Countries from the global North understandably have accumulated specialized skills and capabilities and in all cases the majority of services imports from Europe or North America consisted of modern services. This is particularly the case for Angola and Tanzania, which have lower levels of GDP per capita and appear to be more dependent on external capabilities to supply modern services.

Second, each of these countries was relatively more dependent on exporting traditional services than modern services, although there was evidently some scope for supplying modern services, particularly to other African countries. For instance, roughly 35 per cent of South Africa's exports to SSA consisted of higher-value services. ${ }^{9}$

Overall, SADC economies showed greater capacity for lower-value services exports to the rest of the world whilst being more dependent on imports from outside Africa to supply them with highorder services. There was little sign of SADC countries operating as a regional trade bloc, with unimpressive levels of intra-African services trade. Nevertheless, this also suggests that there is room for growth through import substitution in favour of knowledge-intensive African firms.

\footnotetext{
${ }^{8}$ See Figure 3 for an explanation of the definitions of these categories. 'Government goods and services n.i.e.' is included as a small residual category.

${ }^{9}$ Surprisingly, two-thirds of Angola's exports into Sub-Saharan Africa and other regions consisted of modern services. A closer inspection of the data shows that construction exports (and imports) were unrealistically high and drove most of this result. This is hard to make sense of other than by noting that Angola recorded high levels of construction exports to the world in its balance of payments, and it deserves further scrutiny.
} 
Figure 7: Composition of services exports by sector and region, largest SADC service exporters 2012

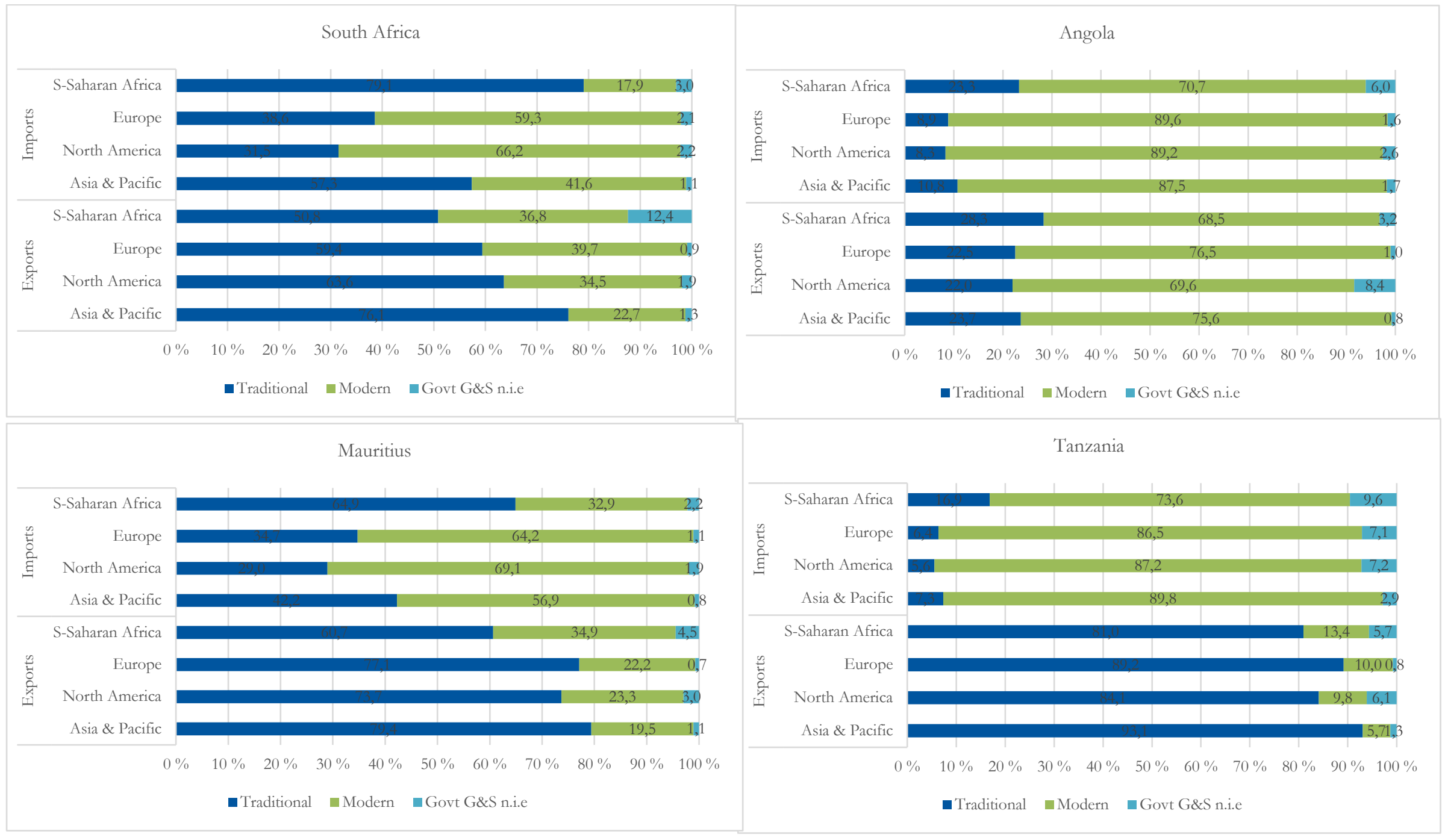

Source: OECD-WTO BaTIS database (2018). 
We end by considering the possible contribution of FDI in services-related industries from South Africa to the rest of the continent. The balance of payments data presented in the previous sections do not account for services traded through a 'commercial presence'. In order to account for this mode of delivery we supplement our analysis with an evaluation of FDI flows.

There may be a number of reasons why firms want to establish a permanent commercial base in a foreign market. These include improving responsiveness to clients, deepening understanding of foreign conditions, improving access to skills with localized knowledge and experience, and complying with terms and conditions for trade imposed by foreign governments. Many service firms depend on a physical presence in the destination market as a mode for delivering their service.

Figure 8 provides a breakdown of the total number of investments and estimated capital contributions to services-based investments from South Africa into countries in SSA over the period 2010-2016. The number of investments is arguably less susceptible to outliers than reported capital commitments, with some differences between these two measures. ${ }^{10}$ Furthermore, capital investments (particularly infrastructure-related) do not necessarily separate out the value-added of services from the creation of physical fixed assets.

Figure 8: Media coverage of South African investment into SSA, all service industries, 2010-2016

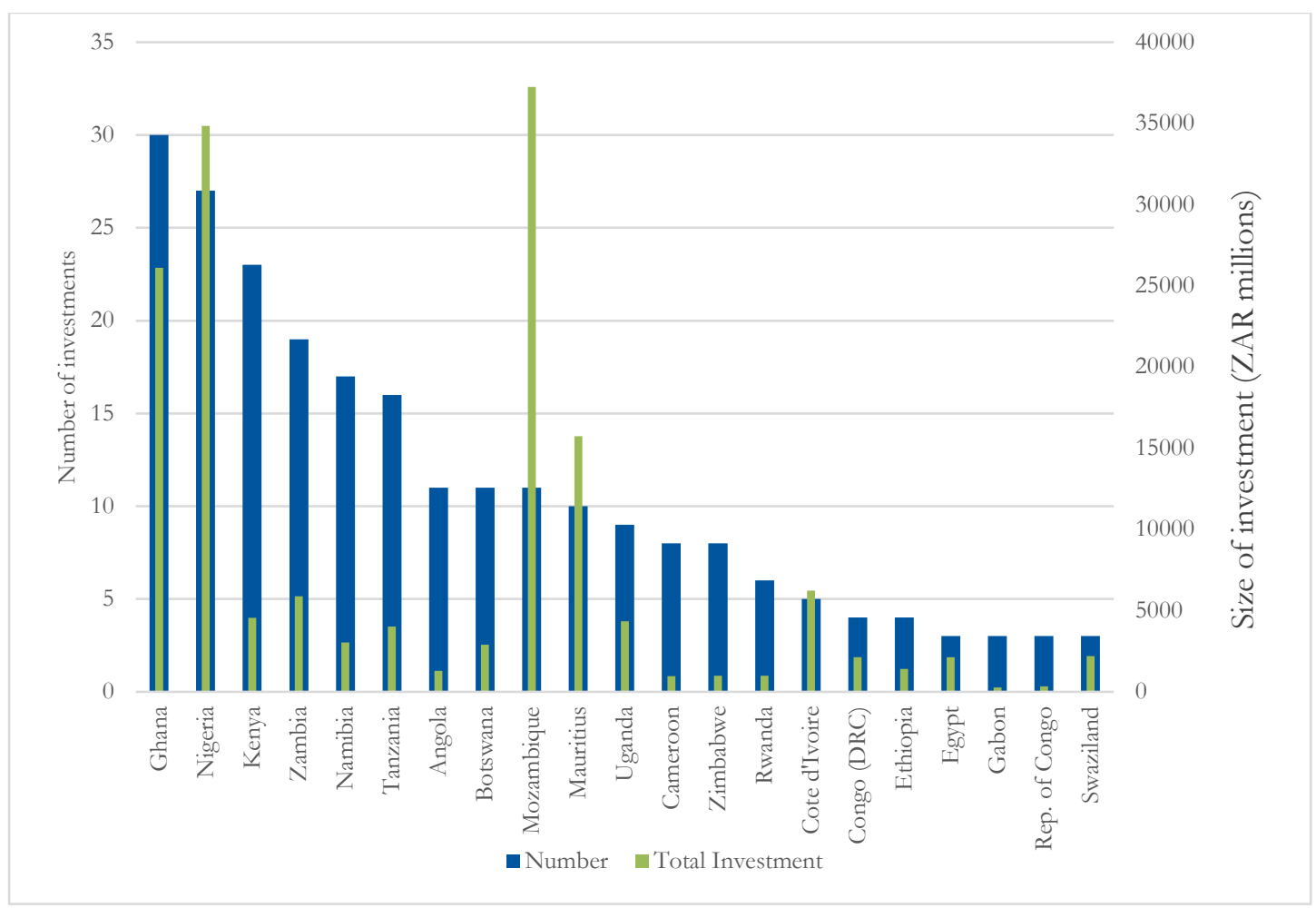

Source: fDi Markets 2018, own estimates.

${ }^{10}$ For example, Mozambique and Mauritius record four very large and identical total capital investments (and estimated number of jobs) from the same source company related to construction in real estate. These estimates are unlikely to be very accurate. 
Figure 9 depicts how investments from South Africa are geographically distributed across Africa using a map. The figure shows that neighbouring countries in Southern Africa generally attract more news headlines than African countries further afield, suggesting some possible advantages to physical proximity. FDI into Madagascar, Malawi, and the DRC was weak-even though these countries are also members of the SADC. The largest sources of FDI corresponded to the potential market size (i.e. total GDP) — in particular, investments into Nigeria, Kenya, and Ghana. This suggests that market size and physical proximity matter more in attracting South African FDI than membership of the SADC, although this observation should be tested with other sources of data and more sophisticated methods.

Figure 9: Map of investments from South Africa into SSA, all service industries, 2010-2016

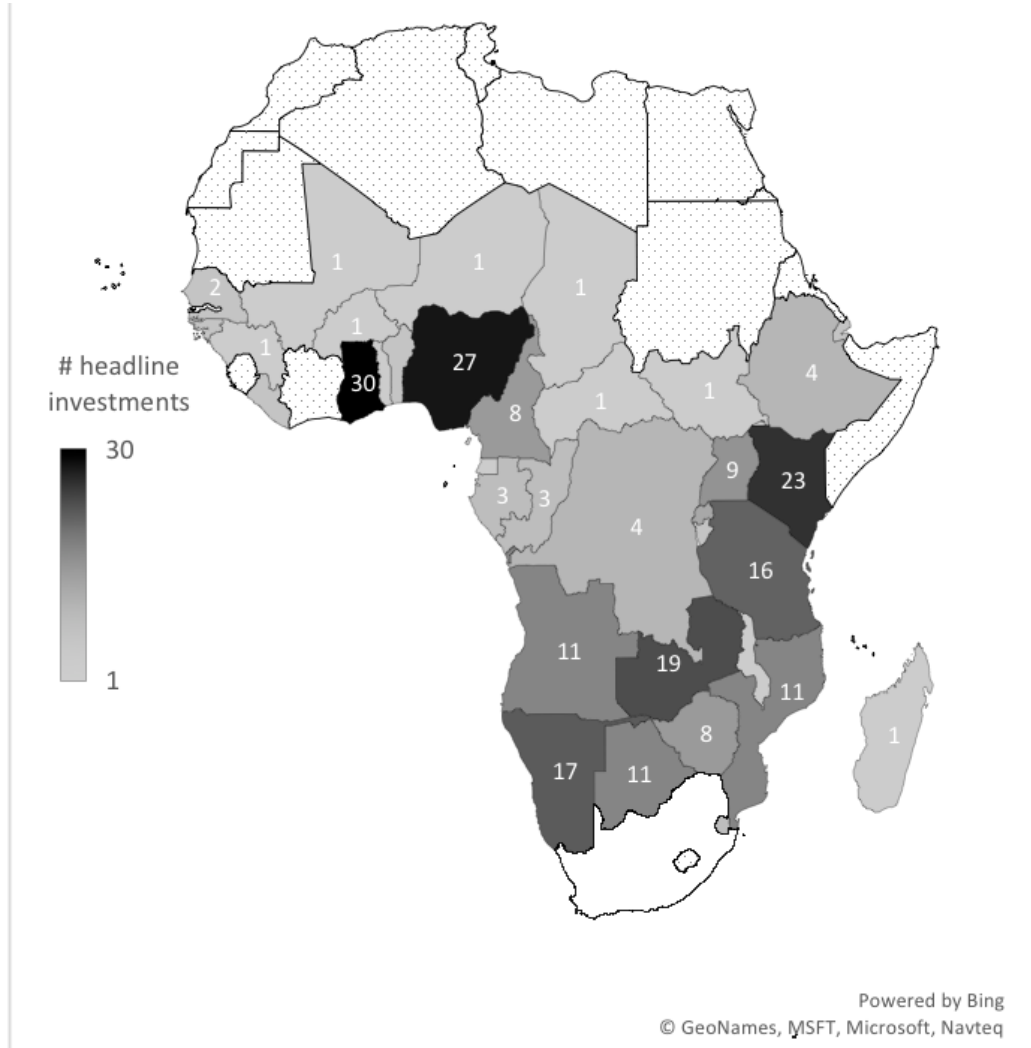

Source: fDi Markets 2018, own estimates.

Figure 10 provides a visual illustration of the types of service sectors that attracted FDI from South Africa over the period. Finance was the largest contributor to investments, reported in the news at 31 per cent, most of which involved the expansion of retail banking. The second largest segment of FDI by South African firms into Africa was in the communications sector, which accounted for 23 per cent of investment news headlines-specifically mobile network operators and broadband/data services. Last, there were a number of smaller but related sectors that focused on servicing assets in the built environment. Combining transport (which relates mostly to pipeline and road infrastructure) and real estate (which includes general construction and tourism) with engineering, waste management, and architecture services (under business services) cumulatively accounted for roughly 20 per cent of news headlines. In fact, if the size of the capital investment is counted (rather than the number of investments), the construction and infrastructure-related sectors accounted for more than half of all FDI reported in the media. This is understandable in the light of the large upfront capital costs involved for investments in infrastructure, although the value-added from these services is admittedly much smaller. Overall, Figure 10 suggests that investments from South African in the finance, telecommunications, and construction-related 
industries attracted relatively more attention than other service sectors in the news media between 2010 and 2016.

Figure 10: Tree map of media coverage of services FDI from South Africa into SSA, 2010-2016

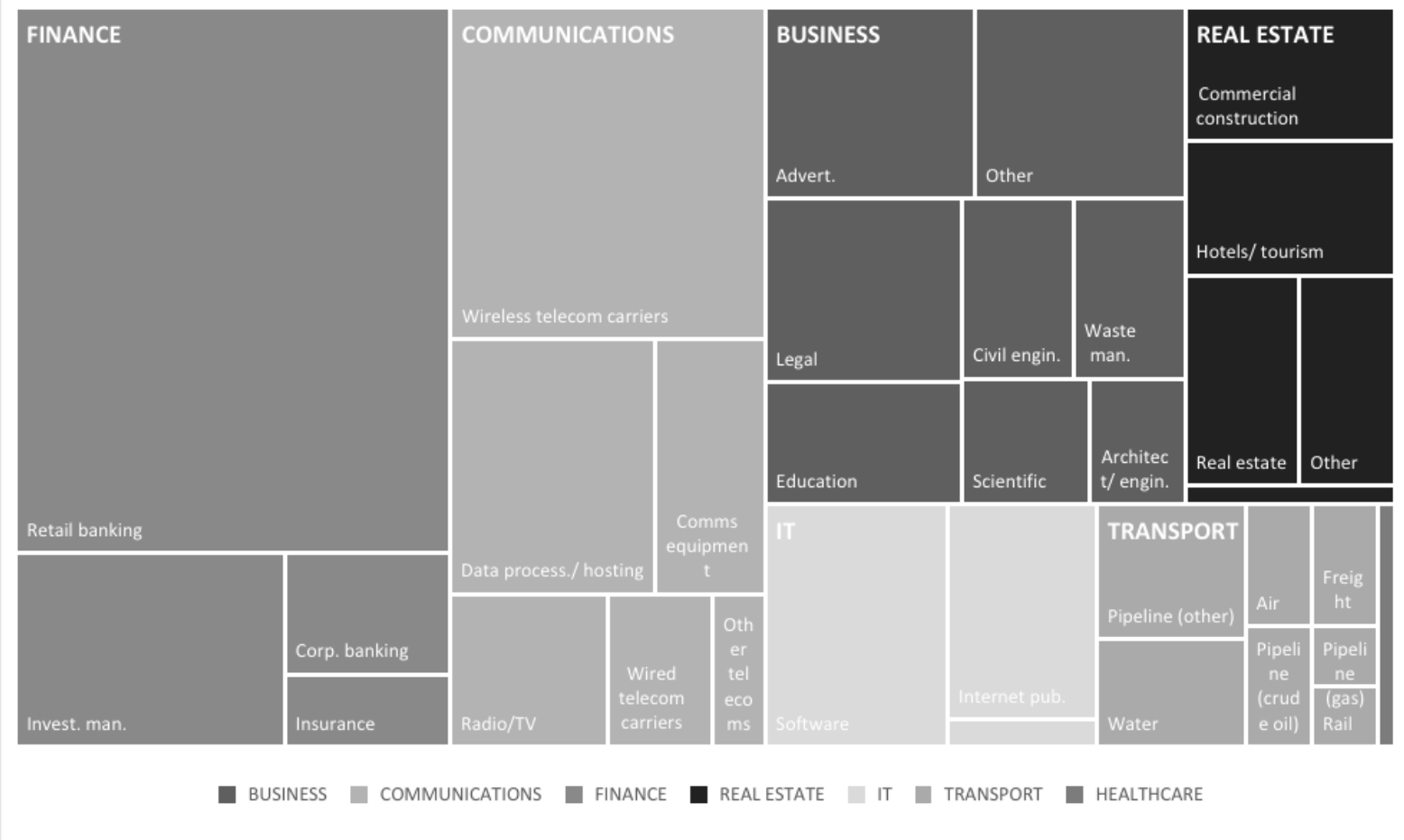

Notes: Based upon number of investments reported in 'headlines'.

Source: fDi Markets, own estimates.

The McKinsey Global Institute (2015) estimates that as much as one-fifth of South Africa's banking revenue is earned from operations in the rest of Africa. Cash-strapped firms in relatively fragile African economies could significantly benefit from the mature and stable financial sector in South Africa. South African banks have developed a strong proficiency in business banking products such as commercial lending, capital market services, and cash management, which could support firms on the ground to expand their operations. Financial institutions in South Africa were actively looking for opportunities in foreign markets in the light of depressed conditions in the domestic market. The related insurance market in Africa is currently very small. Penetration rates are reportedly less than 5 per cent for life and non-life insurance products outside South Africa, and total premiums for the whole of Africa make up less than 1.3 per cent of the global market (McKinsey Global Institute 2015; PWC 2018). Insurance services are predicted to expand rapidly in the next decade through innovations in product offerings catering to lower-income segments of the market and generally as the African consumer class grows.

Supporting the expansion of South Africa-based financial services into the rest of Southern Africa could create win-win scenarios for the region by bolstering South African profits, whilst lowering the costs of doing business and enabling access to working capital across Africa. African countries would do well to adopt a set of shared standards that enable flexibility whilst encouraging transparency and sound oversight. The banking sector in South Africa could look to acquire stakes in existing banks with a knowledge of local conditions and an established consumer base. South African firms need to demonstrate that they can operate more efficiently in African markets than foreign conglomerates. This means offering pricing and product innovations which serve the needs of low-income consumers, such as mobile banking and money-sending applications. 
Improving information and communications technology features as a target in the Sustainable Development Goals and forms the backbone of connectivity and innovation in the digital era. Although mobile subscriptions growth on the continent has outpaced growth in other emerging regions, the costs of data in Sub-Saharan remain the highest in the world (BVA-BDRC 2018; Deloitte 2014). There are obvious reasons for SADC countries to pursue competition and technological upgrading in the telecommunications sector. South Africa's telecommunications industry is one of the most advanced in Africa, with high levels of mobile penetration, growing internet penetration, and steadily expanding infrastructure supporting $3 G$ and $4 G$ connectivity. The South African telecommunication giants have been aggressive in expanding their reach into African markets (MTN 2019; Vodacom 2018). MTN claims to service over 230 million subscriptions, with the largest market share in 14 of the 22 countries in which it operates, including Nigeria, Ghana, Uganda, and Cameroon (MTN 2019). Telecommunications companies are also using their consumer base to diversify their revenue streams by offering services in mobile advertising, mobile banking, business ICT services, and a range of third-party mobile applications. Vodacom and MTN report servicing more than 33 and 22 million customers on their mobile money platforms, respectively (Business Day 2018a).

South Africa's largest telecommunications companies have boasted impressive returns over the past decade and have acquired a dominant position on the continent. However, advancing trade with Africa has been associated with costly regulatory disputes. For example, MTN has been in multiple rows with Nigerian authorities, incurring a US $\$ 2$ billion fine by the Nigerian telecoms regulator for failing to disconnect unregistered users and a US\$53 million fine by the Nigerian Central Bank for the irregular repatriation of dividends to South Africa, and currently being embroiled in disputes in court over US $\$ 2$ billion in outstanding taxes (Business Day 2019).

The construction and engineering industries in South Africa have attracted mixed coverage in the news media. Conditions in the domestic market have steadily deteriorated over the past five years amid declining government spending, hefty industry fines for unfair collusion, and requirements for greater racial equity in ownership when doing business with the state. This has led to widespread downsizing and restructuring amongst South Africa's biggest players. For instance, Basil Read and Group Five posted record losses for 2017, whilst Aveng's annual turnover fell by more than 50 per cent compared with 2014 (Business Day 2018b; Financial Mail 2018). Levels of employment in engineering reportedly fell by 12 per cent in the last six months of 2017 (CESA 2018). The South African government's 'voluntary rebuilding programme' agreement with the sector forced companies to sell off 40 per cent of their equity to black empowerment investors or mentor up to three emerging contractors for seven years. A common criticism from the sector was that price and racial transformation were prioritized above quality and service delivery (Engineering News 2018b). The challenges of doing business with the state have been compounded by a chronic shortage of skilled professionals within government, leading to misspecified and failed tenders, deviations in the planned programme of work, and long delays in project implementation and payment.

Poor prospects within the South African domestic market for construction have fuelled a pursuit of business opportunities in the rest of Africa. For instance, South African construction firm WBHO managed to increase its operating profits in 2017 by growing its revenue from operations in the rest of Africa by 67 per cent, whilst revenue from its South African operations fell by 6 per cent over the same period (Engineering News 2018a). Other construction firms have not been so successful in exporting their services. Group Five has suffered significant losses from misjudgements and delays in the delivery of the Kpone power plant in Ghana. The firm was affected by changes in Ghanaian procurement law and may face up to US $\$ 62.5$ million in penalties (Engineering News 2017). 
A review of the construction sector in Africa by Deloitte (2018) suggests that South African companies remain a small contingent on the continent and account for less than 2 per cent of all construction projects valued at above US $\$ 50$ million, whereas China is responsible for building as many as one-third of such projects and financing up to 20 per cent of infrastructure needs. African construction firms could benefit from more joined-up offerings, leveraging finance, design, engineering, and construction services to provide an integrated package.

\section{Conclusion}

This paper has focused on the contribution of tradable services to trade and development amongst SADC countries. Services have risen in prominence in the modern era of globalized production, and some emerging countries have taken advantage of opportunities for services-based trade. Recent examples include India's ICT sector and health tourism in the Philippines (Eichengreen and Gupta 2011; Ghani 2009; Yi 2012). High-order services are a critical ingredient in raising competitiveness across other sectors but have been relatively neglected in traditional industrial policy. Lower-value services have greater capacity to employ less-skilled labour but may command less influence within value chains. Supporting competitive service industries in Africa could serve the dual purpose of raising productivity amongst manufacturers (and other industries) and growing the share of services as a tradable export. Developments within regional trade agreements on the continent appear to offer new prospects for expanding services trade.

We made use of a comprehensive services trade database released by the OECD and WTO to better understand the nature of international services trade in the SADC region over the period 1995-2012. We found that services exports showed weak growth in the 1990s. Although they appear to have ramped up since the mid-2000s, closer examination of the data suggests that services have tended to lag behind domestic growth rather than lead economic upturns. Moreover, international trade in services made up less than 15 per cent of total goods and services exportswith the notable exceptions of Mauritius and Seychelles. The composition of services exports was heavily skewed towards the traditional sectors of transport and travel, although modern sectors such as IT, finance, and business services registered relatively higher levels of growth.

There was little evidence of regional integration between countries in SSA, with fairly low levels of intra-African service trade. African firms were far more likely to export services into European markets than to their African neighbours. The composition of services imports from more advanced regions was skewed towards modern services, whilst African countries were dependent on exports from traditional services sectors. This could mean that there is room in the future to displace foreign firms once African firms can compete in higher-value services.

South Africa accounted for nearly half of all services exports in the SADC region, where it held a hegemonic position in services trade. The supplementary evidence on flows of services-based FDI suggested that South Africa made relatively greater contributions to finance, telecommunications, and construction-based FDI. There are many examples of South African firms that have successfully expanded operations into the rest Africa, although firms need to demonstrate a thorough understanding of destination markets and must frequently overcome regulatory hurdles. FDI from South Africa seemed to be associated with the proximity and size of the foreign market rather than with membership in the SADC, although this needs to be explored more thoroughly.

In the end, tradable services appeared to hold a fairly limited position in the export basket of most SADC countries, which mostly exported traditional services such as transport or tourism. Modern services may be of greater strategic importance for upgrading capabilities in the rest of the 
economy in the future-and may even offer potential for growth through the displacement of foreign firms - but this would be from a low base. SADC countries did not show much evidence of functioning effectively as a services trade block and displayed low levels of intra-African trade.

The clear implication for policy makers in Southern Africa is that service industries need to be explicitly recognized and supported by industrial policy in order to grow. The supposed choice between manufacturing and services is false and misdirected in the light of their co-dependence and complementarity. Knowledge-intensive services should be recognized for their strategic role in raising productivity and adding value to other sectors. Traditional services sectors have a more direct role to play in creating labour-intensive and less-skilled employment opportunities. An active services policy can play an important role in facilitating healthy domestic competition in services and in opening up access to foreign markets. Policy makers need to update their evidence on the direct and indirect impact of services on the economy and begin to identify priorities for intervention.

Regional trade agreements should seek to develop regional specializations, whereby clusters of related firms benefit from a shared pool of proficient labour, technology spill-overs, and specialized infrastructure. For instance, the AfCFTA should aim to go well beyond the obvious reduction in tariff barriers and begin to address deeper limitations, such as restrictions on foreign equity in establishing a foreign commercial base, differences in standards and rules for licensing and professional accreditation, favouritism in state-related contracts, and restrictions on the immigration of skilled professionals.

Governments should start by listening to private industry and understanding its needs and priorities. It matters a great deal whether the growth of tradable services is mainly constrained by trade barriers, state regulations, and bureaucratic procedures, or by the restricted mindsets, strategies, and internal capabilities of the firms themselves.

More research is needed on how to develop domestic firms' capabilities, whether by boosting the supply of relevant skillsets, fostering business networks, and mutual learning, or by encouraging foreign suppliers to transfer expertise by forming joint ventures with local companies. The right approach may vary in different sectors and could benefit from a series of industry-specific studies. Distinguishing between the performance of multinational enterprises and domestic firms could be important to an understanding of how and why companies grow and develop. Analysing the strength of their embeddedness and linkages to manufacturing, construction, and other branches of the economy is an important part of this assessment.

Finally, the quality of international services trade data for African countries should be improved in accordance with WTO guidelines, as set out in their services statistics handbook. Better data would improve the bases for effective negotiations in trade rounds with the WTO and for regional trade agreements. Better data collection could start with simple things like recording export and import source and destination markets and then move on to revisions in classifications in order to cover more detailed services sub-sectors. A FATS framework should be implemented in the longer term to capture the trade of services through the activities of resident affiliates of foreign companies. 


\section{References}

African Development Bank, Organisation for Economic Co-operation and Development and United Nations Development Program (2017). 'African economic outlook 2017: Entrepreneurship and industrialisation'. Paris: OECD Publishing. http://doi.org/10.1787/aeo-2017-en

Baldwin, R., and J. Lopez-Gonzalez (2015). 'Supply-chain trade: A portrait of global patterns and several testable hypotheses'. World Economics, 38: 1682-721. http://doi.org/10.1111/twec.12189

Bhorat, H., F. Steenkamp, C. Rooney, N. Kachingwe, and A. Lees (2018). 'Understanding and characterizing the services sector in South Africa: An overview'. Development Policy Research Unit Working Paper 201803. University of Cape Town: DPRU.

Business Day (2018a). 'Vodacom spreads its wings to reach new African markets: The mobile operator takes its financial services into new African markets'. 10 May. Available at: https://www.businesslive.co.za/bd/companies/telecoms-and-technology/2018-05-10vodacom-spreads-its-wings-to-reach-new-african-markets/ (accessed 25 January 2019).

Business Day (2018b). 'Group Five's struggles deepen as Kpone delays in Ghana bite: The fullyear loss has deepened and veteran CFO Cristina Teixeira has resigned'. 2 October. Available at: https://www.businesslive.co.za/bd/companies/industrials/2018-10-02-group-fivesstruggles-deepen-as-kpone-delays-in-ghana-bite/ (accessed 25 January 2019).

Business Day (2019). 'MTN stock records its longest slide since 1995: The group's shares have fallen more than $12 \%$ in eight days'. 6 March. Available at: https://www.businesslive.co.za/bd/companies/telecoms-and-technology/2019-03-06mtns-shares-slide-to-worst-level-since-september-2018/ (accessed 10 April 2019).

BVA-BDRC (2018). 'A global study of broadband pricing'. London: BVA-BDRC. Available at: https://www.bva-bdrc.com/opinions/global-study-broadband-pricing/ (accessed 16 April 2019).

Cattaneo, N. (2017). Trade in services negotiations: A Southern African perspective. Geneva: International Centre for Trade and Sustainable Development (ICTSD).

CESA (2018). Bi-annual economic and capacity survey, July-December 2017. Johannesburg: Consulting Engineers South Africa.

Cooke, J. (2017). 'Data on trade and investment services'. In B. Hoekman and D.W. te Velde (eds), Trade in services and economic transformation. London: Overseas Development Institute.

Deloitte (2014). 'The future of telecoms in Africa: The "blueprint for the brave"'. Deloitte Touche Tohmatsu. Available at: https://www2.deloitte.com/za/en/pages/technology-media-andtelecommunications/articles/the-future-of-telecoms-in-africa.html (accessed 10 April 2019).

Deloitte (2018). 'African construction trends report 2018'. Deloitte Touche Tohmatsu. Available at: $\quad$ https://www2.deloitte.com/za/en/pages/energy-and-resources/articles/africaconstruction-trends-report.html (accessed 10 April 2019).

Di Meglio, G., J. Gallego, A. Maroto, and M. Savona (2018). 'Services in developing economies: The deindustrialization debate in perspective'. Development and Change, 49(6): 1495-525. http://doi.org/10.1111/dech.12444

Eichengreen, B., and P. Gupta (2011). 'The service sector as India's road to economic growth'. NBER Working Paper 16757. Cambridge, MA: National Bureau of Economic Research. 
Engineering News (2017). 'Group Five expects material earnings impact as Kpone drags'. 19 December. Available at: www.engineeringnews.co.za/article/group-five-expects-materialearnings-impact-as-kpone-drags-2017-12-19 (accessed 25 January 2019).

Engineering News (2018a). 'WBHO sees 67 per cent jump in profit, believes the cycle has bottomed out'. 27 February. www.engineeringnews.co.za/article/wbho-sees-67-jump-inprofit-believes-the-cycle-has-bottomed-out-2018-02-27/rep_id:4136 (accessed 25 January 2019).

Engineering News (2018b). 'Consulting engineers report positive confidence levels for 2018'. 14 May. Available at: www.engineeringnews.co.za/article/consulting-engineers-report-positiveconfidence-levels-for-2018-2018-05-14/rep_id:4136 (accessed 25 January 2019).

Fessehaie, J. (2017). Leveraging the services sector for inclusive value chains in developing countries. Geneva: International Centre for Trade and Sustainable Development (ICTSD).

Financial Mail (2018). 'Construction sector's crumbling foundations'. 19 April. Available at: https:/ / www.businesslive.co.za/fm/features/cover-story/2018-04-19-construction-sectorscrumbling-foundations/ (accessed 25 January 2019).

Fortanier, F., A. Liberatore, A. Maurer, G. Pilgrim, and L. Thomson (2017). The OECD-WTO balanced trade in services dataset. World Trade Organization and Organisation for Economic Cooperation and Development.

Ghani, E. (2009). 'Is service-led growth a miracle for South Asia?'. In E. Ghani and H. Kharas (eds), The service revolution in South Asia. Washington, DC: World Bank.

Ghani, E., and S. O'Connell (2014). 'Can service be a growth escalator in low-income countries?' World Bank Policy Research Working Paper 6971. Washington, DC: World Bank. http:/ / doi.org/10.1596/1813-9450-6971

Glaeser, E. (2011). Triumph of the city: How our greatest invention makes us richer, smarter, greener, healthier, and happier. London: Penguin.

Gollin, D., R. Jedwab, and D. Vollrath (2016). 'Urbanization with and without industrialization'. Journal of Economic Growth, 21(1): 35-70. Available at: https://EconPapers.repec.org/RePEc:kap:jecgro:v:21:y:2016:i:1:p:35-70 (accessed 16 April 2019).

Hallward-Driemeier, M., and G. Nayyar (2017). Trouble in the making: The future of manufacturing-led development. Washington, DC: World Bank. http://doi.org/10.1596/978-1-4648-1174-6

Heuser, C., and A. Mattoo (2017). 'Services trade and global value chains.' Policy Research Working Paper 8126. Washington, DC: World Bank.

Hoekman, B., and D.W. te Velde (2017). Trade in services and economic transformation. London: Overseas Development Institute.

Kaplinsky, R. (2005). Globalisation, poverty and inequality. Cambridge: Polity Press.

Kaplinsky, R., and M. Morris (2016). 'Thinning and thickening: Productive sector policies in the era of global value chains'. European Journal of Development Research, 28(4), 625-45. http://doi.org/10.1057/ejdr.2015.29

Kruger, P. (2011). 'Services negotiations under the Tripartite Agreement: Issues to consider'. TRALAC Working Paper D11WP10/2011. Stellenbosch: Trade Law Centre.

Loungani, P., S. Mishra, C. Papageorgiou, and K. Wang (2017). 'World trade in services: Evidence from a new dataset'. IMF Working Paper 17(77). Washington, DC: International Monetary Fund (IMF). http:// doi.org/10.5089/9781475589887.001 
McKinsey Global Institute (2015). 'South Africa's Big Five: Bold priorities for inclusive growth. Service exports: Riding the wave of Africa's growth'. New York: McKinsey \& Company.

McKinsey Global Institute (2017). 'Jobs lost, jobs gained: Workforce transitions in a time of automation'. New York: McKinsey \& Company.

McKinsey Global Institute (2019). 'Globalization in transition: The future of trade and value chains’. New York: McKinsey \& Company.

MTN (2019). 'Integrated report for the year ended 31 December 2018'. Johannesburg: MTN Group. Available at: https://www.mtn.com/investors/financial-reporting/integratedreports/ (accessed 16 April 2019).

Nayyar, G., and M.J. Vargas Da Cruz (2018). 'Developing countries and services in the new industrial paradigm'. World Bank Policy Research Working Paper 8659. Washington, DC: World Bank. Available at: https://ssrn.com/abstract=3295386 (accessed 16 April 2019).

Noland, M., D. Park, and G. Estrada (2012). 'Developing the service sector as engine of growth for Asia: An overview'. ADB Economics Working Paper 320. Mandaluyong: Asian Development Bank (ADB). Available at: http://hdl.handle.net/11540/1270 (accessed 16 April 2019).

OECD (2017). Services trade policies and the global economy. Paris: OECD Publishing. http://doi.org/10.1787/9789264275232-en

OECD (2018). Productivity and jobs in a globalised world: (How) can all regions benefit?. Paris: OECD Publishing. http://doi.org/10.1787/9789264293137-en

Parshotam, A. (2018). 'Can the African Continental Free Trade Area offer a new beginning for trade in Africa?' South African Institute of International Affairs Occasional Paper 280. Johannesburg: South African Institute of International Affairs.

PWC (2018). Ready and willing: African insurance industry poised for growth. London: PricewaterhouseCoopers.

Razzaque, M. (2017). 'Using services to promote manufacturing-led structural transformation.' In Hoekman, B., and D.W. te Velde. (eds), Trade in services and economic transformation. London: Overseas Development Institute.

Rodrik, D. (2016). 'Premature deindustrialization'. Journal of Economic Growth, 21(1): 1-33.

Rodrik, D. (2018). 'An African growth miracle?' Journal of African Economies, 27(1): 10-27. http://doi.org/10.1093/jae/ ejw027

Rueda-Cantuche, J.M., R. Kerner, L. Cernat, and V. Ritola (2016). 'Trade in services by GATS: Modes of supply, statistical concepts and first EU estimates'. Chief Economist Note, Issue 3, November. Brussels: European Commission.

SADC (2015). 'The Southern African Development Community (SADC) Regional Industrialisation Strategy and Roadmap 2015-2063'. Harare: Southern African Development Community.

Stephenson, S., and J. Drake-Brockman (2014). 'The services trade dimension of global value chains: Policy implications for Commonwealth developing countries and small states'. Commonwealth Trade Policy Discussion Paper 4/2014. London: Commonwealth Secretariat.

Storper, M., T. Kemeny, N. Makarem, and T. Osman (2015). 'The rise and fall of urban economies: Lessons from San Francisco and Los Angeles'. Palo Alto: Stanford University Press. 
Vodacom (2018). 'Integrated report for the year ended 31 March 2018'. Midrand, South Africa: Vodacom. Available at: https://www.vodacom.com/integrated-reports.php (accessed 16 April 2019).

United Nations Economic Commission for Africa (2018). African Continental Free Trade Area: Questions \& answers. African Trade Policy Centre of the Economic Commission for Africa. Addis Ababa: African Trade Policy Centre (ATPC).

World Bank (2018). 'An incomplete transition: Overcoming the legacy of exclusion in South Africa'. Republic of South Africa Systematic Country Diagnostic Report 125838-ZA. Washington, DC: World Bank.

World Bank (2019). 'World Development Report 2019: The changing nature of work.' Washington, DC: World Bank. http:/ / doi.org/10.1596/978-1-4648-1328-3

World Economic Forum (2016). 'The future of jobs: Employment, skills and workforce strategy for the fourth industrial revolution'. Global Challenge Insight Report. Geneva: World Economic Forum.

WTO (2016). 'World Trade Statistical Review 2016'. Geneva: World Trade Organization.

WTO (2016). 'World Trade Statistical Review 2017’. Geneva: World Trade Organization.

Yi, S. (2012) 'Reaching the world through private sector initiative: Service exports from the Philippines'. In A. Goswami, A. Mattoo, and S. Sáez (eds), Exporting services: A developing-country perspective (pp. 121-60). Washington, DC: World Bank. 